\title{
Tract of Burdach
}

National Cancer Institute

\section{Source}

National Cancer Institute. Tract of Burdach. NCI Thesaurus. Code C33798.

A bundle of axon fibers and a sensory (ascending) tract in the lateral portions of the dorsal columns of the spinal cord lying between the posterolateral sulcus and the anterolateral sulcus, which transmits information from the upper half of the body. 